George S. Yip is Dean of Rotterdam School of Management, Erasmus University; and a Fellow of the UK's Advanced Institute of Management Research, of the Academy of International Business, and of the International Academy of Management. He has been a professor at UCLA, Cambrige Universty, and London Bushess School, and has held other posts at Harvard and stanford bushess schools. His extentive buskess experence includes being Vice President and Director of Research \& lnnovation at Capgenni Consuling, and man School.

Multinational companies need to manage their relationships with multinational customers in a globally integrated approach. This booklet provides a systematic framework for developing and implementing such global customer management programmes. It is based on Chapter 1 of George S. Yip and Audrey Bink, Managing Global Customers: An Integrated Approach, Oxford University Press, 2007. The authors' research takes more than just sales approach; it takes a strategic and total business approach to managing global customers from the customer perspective as well as that of the supplier.

The Erasmus Research Institute of Management (ERIM) is the Research School (Onderzoekschool) in the field of management of the Erasmus University Rotterdam. The zoekschol) in the fteld of management of Erasmus School of Economics (ESE). ERIM was founded in 1999 and is officilly accredited by the Royl Netherlands Ac (Ke) by ERIM is focused on the management of the firm in its environment, its intra- and interfirn relations, and its business processes in their interdependent connections-

The objective of ERli is to carry out first rate research in management, and to offer an advanced doctoral program and PhD candidates are active in the different research programmes. From a variety of academic backgrounds and expertises, the ERIM community is united in striving for excellence and working at the forefront of creating new business knowledge.

Inaugural Addresses Research in Management contain written texts of inaugural dresses by members of ERIM. The addresses are avallable in two ways, as printed

\section{Managing Global Customers}

Prof.Dr. George S. Yip

Dean Rotterdam School of Management (RSM)

Erasmus University
Inaugural Address Series Research in Management

$\begin{array}{lll}\text { Erasmus Research Institute of Management - ERIM } & \text { Tel. } & +31104081182 \\ \text { Rotterdam School of Management (RSM) } & \text { Fax } & +31104089640 \\ \text { Erasmus School of Economics (ESE) } & \text { E-mail } & \text { info@erim.eur.nI } \\ \text { P.O. Box 1738, 3000 DR Rotterdam } & \text { Internet } & \text { www.erim.eur.nl }\end{array}$

P.O. Box 1738, 3000 DR Rotterdam

Internet www.erim.eur.nl 
Managing Global Customers 
Bibliographical Data and Classifications

Library of Congress Classification

F 5001-6182

http://lcweb.loc.gov/catdir/cpso/lcco/lcco.h.pd

Journal of Economic Literature

(JEL)

http://www.aeaweb.org/journal/jel_class_system.htm

21, L2

Gemeenschappelijke Onderwerpsontsluiting (GOO)

Classification GOO

85.00

Keywords GOO

Bedrijfskunde / Bedrijfseconomie

Strategisch management

Organisatievernieuwing,

Multinationals, Klantgerichtheid

redes (vorm)

Global account management

Global customers

Global marketing

rasmus Research Institute of Management - ERIM

Rotterdam School of Management (RSM)

Erasmus School of Economics (ESE)

Erasmus Universiteit Rotterdam

Internet: www.erim.eur.nl

ERIM Electronic Series Portal:

http://hdl.handle.net $/ 1765 / 1$

Inaugural Addresses Research in Management Series

Reference number ERIM: EIA-2009-038-STR

ISBN/EAN 978-90-5892-213-7

(๑) 2009, George S.Yip

Design and layout: B\&T Ontwerp en advies (www.b-en-t.nl)

Print: Haveka (wwwhavekanl)

All rights reserved. No part of this publication may be reproduced or transmitted in any form or by any means electronic or mechanical, including photocopying, recording, or by any information storage and retrieval system,

without permission in writing from the author(s).

\section{Managing Global Customers}

Inaugural Address

Address given in shortened form at the occasion of accepting the appointment as Professor of Clobal Strategy and Management at the Rotterdam School of Management

Erasmus University Rotterdam on Friday, June 19, 2009

by

Prof.Dr. George S. Yip

Rotterdam School of Management

Erasmus University Rotterdam

P.O. Box 1738

3000 DR Rotterdam

The Netherlands

E-mail: gyip@rsm.nl 


\section{Samenvatting}

Multinationale bedrijven dienen hun relaties met multinationale klanten met een wereldwijd geïntegreerde aanpak te beheren. Deze oratie biedt een systematisch kader voor het ontwikkelen en implementeren van programma's voor wereldwijd klantenbeheer. De voordracht is gebaseerd op hoofdstuk 1 van het boek van George Yip en Audrey Bink, "Managing Global Customers, an integrated approach", Oxford University Press, 20007.

Dit boek heeft een strategische, geheel zakelijke en niet alleen op de verkoop gerichte aanpak voor het wereldwijd beheren van zakelijke relaties, niet alleen vanuit het perspectief van klant maar ook vanuit het oogpunt van de leverancier. Het boek biedt een systematische en logische aanpak maar is tevens voorzien van creatieve inzichten en praktische adviezen.

Het primair ondersteunend onderzoek is wereldwijd gehouden bij 22 multinationale ondernemingen, zowel leveranciers als klanten. Voor dit onderzoek zijn 60 hoge kaderleden persoonlijk geïnterviewd en hebben 27 kaderleden een gedetailleerde enquête ingevuld. Wij hebben informatie verkregen over de wijze waarop klant / leverancier programma's het beste uitgevoerd kunnen worden, welke obstakels men tegen kan komen en welke "best practices" tot een extra voordeel kunnen leiden.

\section{Summary}

Multinational companies need to manage their relationships with multinational customers in a globally integrated approach. This paper provides a systematic framework for developing and implementing such global customer management programmes. The paper is based on Chapter 1 of George S. Yip and Audrey Bink, Managing Global Customers: An Integrated Approach, Oxford University Press, 2007.

The book takes a strategic, total business, and not just sales approach to managing global customers. It also takes a customer as well as a supplier perspective. The book provides guidance on both strategy and implementation. Lastly, the book takes a systematic and logic driven approach, yet provides many creative insights and practical advice.

The primary supporting research is a study on global customer-supplier management with primary research conducted at 22 multinational companies, both global suppliers and global customers. This research involved personal interviews with over 60 senior executives, as well as a detailed multi-level survey completed by 27 executives. The authors obtained information on the way global customer-supplier relationship programmes can be implemented, the barriers that can be encountered and best practices that can lead to extra advantage. 


\section{Short Biography}

George S. Yip is the Dean of the Rotterdam School of Management, Erasmus University Rotterdam since January 2008.

He holds B.A. and M.A. degrees in economics from Cambridge University; and an MBA and doctorate from Harvard Business School. A native of Asia, he is a dual citizen of the United Kingdom and of the United States. George is one of the world's leading authorities on global strategy and marketing, managing global customers, and internationalisation. His current research concerns management innovation, strategic transformation, international competitiveness, and global customers.

Before joining RSM, Yip was Vice President and Director of Research \& Innovation at Capgemini Consulting, where he managed the research and innovation process to develop thought leadership for the company. During this time he was on leave of absence as Professor of Strategic and International Management at London Business School. He was previously the Chair of Marketing and Strategy at Cambridge University, and has also held faculty positions at Harvard Business School and UCLA, and visiting positions at China-Europe International Business School, Georgetown University, Stanford Business School, and Templeton College-Oxford.

George also has 12 years of full-time business experience in international business, marketing, and strategy, working in the United States and the United Kingdom. This experience includes product management with Unilever; account management with Lintas, one of the world's largest advertising agencies; and senior manager of Price Waterhouse's strategic management consulting services in the Eastern United States.

George Yip is a Fellow of the Advanced Institute of Management Research, which is the UK's research initiative on management (www.aimresearch.org), and a Fellow of the Academy of International Business. His latest book is Managing Global Customers (Oxford University Press, 2007). An earlier book, Total Global Strategy: Managing for Worldwide Competitive Advantage (Prentice Hall, 1992; 1995) was selected as one of the 30 best business books of 1992; has been published in ten languages, and updated as Total Global Strategy II (2003).

\section{Content}

Summary

Short Biography

Content

Managing Global Customers

The Globalisation Context for Managing Global Customers

The Globalisation of Buying and Selling

Global Account Management

The Integrated Approach

Supporting Research 


\section{Managing Global Customers}

"I am sorry but we are dropping your company as a supplier because you are unable to serve us on a globally integrated basis."

"I am pleased to tell you that we have designated your company as a worldwide supplier because you have demonstrated your ability to serve us on a globally integrated basis."

Multinational suppliers are increasingly hearing one or the other of the above two messages from their multinational customers. What is happening is a sea change in the way in which multinational customers and multinational suppliers work with each other. The old operating mode was that the national subsidiaries of multinational companies (MNCs) were free to make their own decisions about suppliers. This often meant that different national subsidiaries of one MNC customer might be buying from the national subsidiaries of an MNC supplier, but the relationships would be between national subsidiaries and not at the company level. Figure 1 illustrates this mode of relationship, which we term "multilocal buying." Of course, there can be other variations, such as a customer in Country A buying from the same or different suppliers in several countries. But the central aspect of this mode is that subsidiaries make their own choices.

\begin{tabular}{|l|l|l|}
\multicolumn{1}{l}{ Customer } & \multicolumn{1}{l}{ Supplier } \\
\hline Country A & $\rightarrow$ & Country A \\
\hline Country B & $\longrightarrow$ & Country B \\
\hline Country C & $\longrightarrow$ & Country C \\
\hline Country D & $\rightarrow$ & Country D \\
\hline
\end{tabular}

Figure 1-Multilocal Buying 


\section{The Globalisation Context for Managing Global Customers}

The need to manage customers on a global basis arises in the context of the ongoing globalisation of countries, industries, and companies. In terms of countries, every major economy and most minor ones participate in the larger global economy, albeit with varying degrees of openness. Many countries have joined trading and other economic blocs, such as the European Union, ASEAN, or NAFTA, in which trade, investment and othe business cross-border barriers have been drastically reduced. The net effect is that most companies now have very wide geographic choices in terms of both where they sell and where they source. For example, Wal-Mart alone accounts for more than 10 per cent of all of the United States' annual imports from China, and more than either Russia's or Britain's imports. Also, as multinational companies expand the geographic scope of their activities, they expect their suppliers to follow them. In turn this spread raises the bar in terms of the scope in managing customer relationships on a global basis.

In terms of industries, competition increasingly occurs across as well as within national borders, although the extent of globalisation varies by industry, depending largely on industry globalisation drivers. These drivers include the salience of national culture, economies of scale, and regulation. ${ }^{1}$ The industries with the strongest globalisation drivers require competitors in them to respond with globally integrated strategies. ${ }^{2}$

In terms of companies, these globally integrated strategies include global market participation. C. Michael Armstrong, CEO of AT\&T, was referring to this aspect of global strategy when he said: "In the future there will be two kinds of corporations; those that go global and those that go bankrupt."3

Other strategies include global products and services, global location and coordination of activities, global marketing, global competitive moves, and global organisation and management.

1 For a full discussion of industry globalisation drivers, see Chapter 2 in George S. Yip, Total Global Strategy Il: Updated for the Internet and Service Era, Upper Saddle River, NJ: Prentice Hall, 2003.

2 For a review of global strategy see George S. Yip, (1989), 'Clobal Strategy...In a World of Nations?' Sloan Management Review, 31, 1, 29-41; and George S. Yip, Total Global Strategy II: Updated for the Internet and Service Era, Upper Saddle River, NJ: Prentice Hall, 2003.

3 M.Gabel, H.Bruner. Global Inc. New Press, New York, 2003.

\section{The Globalisation of Buying and Selling}

So in response to globalisation, both multinational customers and suppliers are adopting various aspects of global strategy. Customers who use global purchasing can be viewed as pursuing the strategy of global coordination of activities. Suppliers who manage customers globally can be viewed as pursuing the strategy of global marketing.

Changes in Multinational Buyer Behaviour

In the global era, multinational customers increasingly seek to deal on a globally coordinated basis with their suppliers, demanding such services as global contracts, global pricing, product standardisation and a global account relationship. For example, in their drives to reduce costs, major automobile manufacturers such as General Motors and Ford increasingly seek global contracts from their suppliers, such as Bosch and Goodyear. Nestlé and its competitors increasingly pressure their suppliers, such as International Paper, to provide global prices and other terms. Even retailers, such as WalMart and Carrefour, which have long taken national approaches, are seeking global or regional supply contracts as they expand globally.

Historically, most multinational companies have allowed their national subsidiaries extensive independence in their purchasing behaviour, but the problems found with this approach (e.g., incompatibility of equipment and standards, and diseconomies in purchasing) have increasingly led them to buy on a more centralised or coordinated basis. Also, as multinational companies themselves develop more globally integrated strategies, they expect the same from their suppliers.

The electronics giant and Dutch MNC, Philips illustrates this change in global purchasing behaviour. Until 2003, each Philips business unit was responsible for the procurement of its own supplies. 4 As purchases equate to approximately two-thirds of Philips' revenues, the company launched a new supply management strategy that should make procurement cheaper and more efficient.

4 See "Smarter links in the modern supply chain", Financial Times, 8 November 2005, p.13. 
Whereas some companies decide to centralise all procurement in one central function in order to cut costs, Philips decided to combine economies of scale with rapid decisionmaking tied closely to the needs of its different businesses. In the new model, each of the five business groups has a central purchasing officer with responsibility for groupwide procurement of specific commodities. For example, the lighting division is responsible for procuring all the group's packaging while the consumer electronics division buys all its plastics. To keep the link with the other businesses, each central purchasing officer has a team dispersed around the different businesses.

Since 2003 Philips has cut the total number of its suppliers from 50,000 to 33,000 . The percentage of combined (i.e., multi-unit) purchases, either for specific businesses or for the group as a whole, has risen from 6 per cent to 55 per cent. In 2005 the target for procurement savings was 16 per cent, and Philips was well on its way to reaching that target. Another part of the new procurement programme is forging closer relationships with a number of key suppliers, which Philips describes as "partners for growth". These key suppliers are increasingly involved in innovation at an early stage. In 2005 they provided 26 per cent of the group's purchases. Barbara Kux, Philips' first chief procurement officer said: "It is a two-way process. We ask each other: what can we do better together? There are always great ideas from our suppliers". One example is the Philishave Coolskin shaver, for which Philips worked with Beiersdorf to make a soothing skin balm under the Nivea brand name.

Even the supermarket sector, one of the least globalisable of industries because of its strong local nature, is moving toward regional and global buying. A 1999 study by a leading consulting firm found that MNC suppliers to supermarkets faced increasing pressures as retailing giants such as Carrefour, Tesco, and Wal-Mart both expanded into more and more countries and also accelerated their extent of regional or global buying. ${ }^{5}$ As a global customer of Philips', Wal-Mart's annual purchases of over \$1 billion are larger than many of Philips' own businesses, such as shaving products.
As far back as 1997, a survey of 191 senior executives in 165 major multinational companies found that their multinational customers were increasingly demanding global consistency in service quality and performance, global contracts, uniform terms of trade, global pricing and the like. In turn, these multinational suppliers were responding with more use of global customer management programmes. ${ }^{6}$

\section{Changes in Multinational Seller Behaviour}

Most multinational suppliers find it very difficult to respond to the demand for global service. Their own organisation structures and management processes have long been geared toward providing national, rather than global customer management. But the savvier suppliers, such as AT\&T, Bank of America, British Telecom, Citibank, IBM, Hewlett-Packard, and Xerox are learning to play the new game of global customer management and reaping the corresponding rewards. This book is about how suppliers can play this game more successfully, and secondarily about how customers can play their part. Managing customers and suppliers on a globally integrated basis can be viewed as a form of global customer-supplier relationship. As illustrated in Figure 2 such relationships typically involve coordination by global units on both customer and supplier sides. On the customer side such a global unit may be the global purchasing function. On the supplier side, such a global unit may be a global account management function. This book concerns how to manage these global customer-supplier relationships, especially from the viewpoint of the supplier.

Advertising agencies provide a strong example of an industry effect. Many advertising agencies have seen a real trend of supplier rationalisation amongst their largest customers. Instead of working with up to a hundred different agencies worldwide, clients increasingly want to work as much as possible with as few as possible suppliers. They do so for two reasons: to achieve greater global consistency in their communications messages and to achieve greater global coordination of their purchasing.

5 McKinsey \& Company, “Managing International Retailers," London, 1999.

${ }^{6}$ David B. Montgomery and George S. Yip, "The Challenge of Global Customer Management," Marketing

Management, 9 (4), 200o, pp. 22-29. 


\begin{tabular}{|l|l|l|l|}
\hline Country A & \multicolumn{1}{|c|}{ Supplier } \\
\hline Country B & Country A \\
\hline Country C & Unit & Clobal & Country B \\
\hline Country D & & & \\
\hline
\end{tabular}

Figure 2 - Global Customer-Supplier Relationship

Particularly in the 1980s, many major advertising agencies faced some globalisation drivers that spurred them to adopt global account management.7 First, some of their major clients, such as Procter \& Gamble and Unilever, were themselves embracing globally integrated strategy and starting to act as global customers. This change in behaviour included increasing use of globally standardised advertising, ${ }^{8}$ e.g., CocaCola's sports hero/little boy campaign of the 1970s, British Airways' repositioning in the early 1980s, and Toyota's global campaign introducing its new Camry model in the early 1990s, (all partly legitimised by Theodore Levitt's 1983 proclamation of the globalisation of markets). ${ }^{9}$ Second, one agency, Saatchi \& Saatchi in its prime aggressively positioned itself as the global agency, spurring its rivals to respond.

7 George S. Yip and Tammy L. Madsen (1996), “Global Account Management: The New Frontier in Relationship Marketing," International Marketing Review, 13 (3), pp. 24-42.

8 Dean M. Peebles, "Don't Write Off Global Advertising: A Commentary," International Marketing Review, Vol. 6, No. 1, 1989, pp. 73-78.

9 Theodore Levitt, "The globalization of markets," Harvard Business Review, May-June 1983, pp. 92-102.
Even a stellar creative reputation cannot save an advertising agency from the demands of global account management. In late 1993, Chiat Day, a U.S.-based creative superstar among agencies, had the Apple Macintosh "1984" commercial and other gems to its credit, but little in the way of an international network. It was dropped by Reebok International, the manufacturer of athletic shoes. Instead, Reebok consolidated its $\$ 140$ million worldwide advertising account at Leo Burnett, a top 10 international network. A key reason cited by Reebok's VP-marketing services worldwide was that Chiat Day did not have the global resources the company needed. Reebok had "wired together a global network using Chiat as the lead agency and Burnett and Euro RSCG (Paris-based) overseas, but there was no partnership between the three." ${ }^{10}$ Soon after the loss of this account, Chiat Day agreed to be acquired by Omnicom Group in early 1995, and to be folded into the latter's TBWA network.

The trend toward global account management in the advertising business has perhaps been the major factor behind the top 10 international agency networks steadily increasing their share of global advertising spending. ${ }^{11}$ Most dramatic of all, in 1994 IBM's new CEO, Louis V. Gerstner, Jr. initiated the firing of over 40 different agencies around the world, and consolidated the company's entire $\$ 400$ to $\$ 500$ million account at one top 10 global agency, Ogilvy \& Mather Worldwide (part of WPP, one of the largest agency groups).

Many MNCs are using the need to serve customers globally as the basis for reorienting themselves from product- and geography-led organisations to becoming customer-led. For example, Reuters, the business information company initiated just such a move in the early 2000 in order to better serve its top 22 global customers. In 2001 Reuters listed these top global customers, in Europe: ABN Amro, Allianz, BNP Paribas, Commerzbank, Credit Suisse, Deutsche Bank, HSBC, Ing, Société Générale and UBS; USA: Bank of America, Citigroup, Fidelity, Goldman Sachs, Instinet, JP Morgan Chase, Lehman Brothers, Merrill Lynch, and Morgan Stanley Dean Witter; and Japan: Mitsubishi Tokyo Financial, Mizuho Holdings, and Putnam.

10 Pat Sloan, Advertising Age, “Why Reebok fired Chiat, once and for all," September 30, 1993, p. 13, 158.

"From 23 per cent to 48 per cent over the 10-year period to 1993. See Laurel Wentz, Advertising Age, "Shops flourish in '9os: Decade of alignment," September 30, 1993, p. 11, 110. 
In the early 2000s, both IBM and Hewlett-Packard went so far as to break out their top 100 or so global accounts from the rest of the organisation as separate businesses with their own profit and loss statements. Indeed, one of the few positives during Hewlett Packard's troubles of the early 2000 s came from the success of its global accounts programme.

\section{Global Account Management}

We now examine the key response by suppliers to the globalisation of buying and selling - global account management. ${ }^{12}$

From National Account Management to Global Account Management

In response to customers' demands for global coordination, MNC suppliers are increasingly adopting global account management (GAM). Companies around the world have long used national account management to handle their most important accounts. Such national account management approaches include having one executive or team take overall responsibility for all aspects of a customer's business, whether directly or coordinating the activities of others. ${ }^{13}$ Typical applications include the use of national account managers for retail chains, for business equipment and service customers. National account management approaches have also been used interchangeably with relationship marketing and management. ${ }^{14}$ The Global Account Management concept extends national account management across countries, not necessarily to all countries, but to the most important ones for the most important customers and for the most important activities. Global account management can also be viewed as the new frontier in "relationship marketing."15

${ }^{12}$ Global purchasing by customers is the other key response but is not the central subject of this book. Se instead, Philip B. Schary and Tage Skjott-Larsen (2001), “Managing the Global Supply Chain,” 2nd. Edition. Copenhagen: Copenhagen Business School Press.

13 Benson P. Shapiro, "Close Encounters of the Four Kinds: Managing Customers in a Rapidly Changing Environment," Harvard Business School, Boston, MA, Note No. 9-589-015, 1989; and Benson P. Shapiro, and Rowland T. Moriarty, “National Account Management: Emerging Insights,” Report No. 80-104, Marketing Science Institute, Cambridge, MA, 1980

14 Barbara B. Jackson, Winning and Keeping Industrial Customers, Lexington Books, New York, 1985.

15 Yip and Madsen (1996). See also Atul Parvatiyar and Thomas Gruen, "Clobal Account Management Effectiveness:" A Contingency Model," working paper, Goizueta School of Business, Emory University, Atlanta, GA, May 25, 2001.GAM can also be viewed as an extension of relationship marketing. For a discussion of the latter concept see, for example, U. Manohar Kalwani and Narakesari Narayandas, "LongTerm Manufacturer-Supplier Relationships: Do They Pay Off for Supplier Firms?" Journal of Marketing, 59 (1995), pp. 1-16; and Christian Grönroos, "Value-Driven Relational Marketing: From Products to Resources and Competencies," Journal of Marketing Management, 13 (5), 1997, pp. 407-420. 
Different companies use different terms such as "global account management," "parent account management," "international account management," or "worldwide account management." Although we will use the first term, the most common one in this book, all these terms define an organisational form and process in multinational companies by which the worldwide activities serving one or more multinational customers are coordinated centrally by one person or team within the supplier company. Global account management can be expensive to implement and carries its own risks such as standardising global prices at a low common level so managers need to be able to diagnose the extent to which their customers will want such services, what sort of services to provide, and how to implement the programmes.

Correspondingly, multinational suppliers are creating global account management programmes with such features as global account managers, double counting of revenues to incentivise both global and national sales people, and global measurement of customer revenues and profits. ${ }^{16}$ Common objectives for these global programmes are increased account revenues, joint innovation and customer lock-in.
Should A Company Adopt Global Account Management?

GAM sounds promising, and for some companies it seems inevitable to keep up with the competition, but it is a costly exercise and therefore it is necessary for the GAM programme to bring some visible extra revenue to the company. GAM has the potential to be a very valuable asset to the company if it is handled in the right way. The benefits of GAM also depend greatly on the product or service involved. The comments of a purchasing manager at the giant engineering company Asea Brown Boveri (ABB) illustrate this:

"It is a combination of volume, how big is the spend, how big is the potential leverage and the globalisation of the supplier. For example, electrical energy is high in volume but a domestic service. It is not a global commodity, whereas credit cards, for example, are a globally available product. So we will implement credit cards globally and energy locally. It is the product that decides if it makes sense to have a global process for procurement."

GAM programmes are not cheap. They involve adding personnel, processes and direct expenses such as travel and collection of information. They also carry risks. The dominant fear is that a globally coordinated approach to a multinational customer merely allows that customer to extract greater concessions. ${ }^{17}$ Such concessions may swamp the various possible benefits. Often, companies are reluctant to implement a GAM programme because of the risks involved, especially a potentially unbalanced relationship and the seemingly inevitable price squeeze.

On the other hand, there is plenty of evidence that GAM programmes work. One study found that GAM programmes were estimated to have a 20 per cent improvement on overall customer satisfaction, about 15 per cent on revenues, and about 15 per cent on profits. ${ }^{18}$ These benefits in GAM programmes have also been reported by a number of 
companies such as Asea Brown Boveri, ${ }^{19}$ Adidas-Salomon, ${ }^{20}$ Hewlett-Packard,,${ }^{21}$ and the advertising agency Young \& Rubicam. ${ }^{22}$

GAM programmes are also very demanding of the implementing company's capabilities for global integration and coordination. A company has to be truly global before a programme for global relations has any chance of success. This may sound trivial, but often companies have a higher perception of their own global capabilities than they actually have. A global account manager from Unisys, the U.S. computer company, remarked: "if a company says global account selling is easy, they probably haven't actually been doing it." Therefore, an assessment of the company's own global situation and capabilities is a good place to start.

Global Account Management as an Organisational Response

GAM can be seen as an organisational response to a changed business environment. A study in 2006 even identified GAM as one of the 100 most significant management innovations in business history, and one of the 11 most interesting recent ones (from 1987 to 2000). ${ }^{23}$ The study cited Hewlett-Packard as being the first company to develop a formal GAM programme that was implemented by its first director of global accounts Alan Nonnenberg, although Citibank had a form of GAM programme as early as $1975 .{ }^{24}$

19 Anton Fritschi, (1999), "Global Key Account Management bei ABB: Erfolg Kennt Keine (Länder-) Grenzen, Thexis, 4: 26-29.

${ }^{20}$ Momani, Faris and Tobias Richter (1999), "Standardisation versus Differentation in European Key Account Management: The Case of the adidas-Salomon AG," Thexis, 4:44-47.

21 Yip and Madsen, 1996.

${ }^{22}$ Angela Andal-Ancion and George S. Yip (2004), "Star Alliance (B): A Global Customer,' Cranfield, U.K. European Case Clearing House, No. 504-128-1.

23 Julian Birkinshaw and Michael Mol, "How Management Innovation Happens, " MIT Sloan Management Review, Vol. 47, No. 4, pp. 81-88.

24 Robert D. Buzzell, “Citibank: Marketing to Multinational Customers," Harvard Business School case No. 9 584-016, Boston, MA.: Harvard Case Services, 1984, revised 1/85
From the perspective of organisational innovation, GAM can be seen as particularly affecting two capabilities: information processing and bargaining power. ${ }^{25}$ First, GAM increases the information processing capacity of the organisation in response to increased information processing demands. ${ }^{26}$ Throughout this book, we will discuss how GAM programmes need to use information effectively. Second, GAM programmes affect the relative bargaining power of suppliers and customers and the way in which they depend on each other. ${ }^{27}$ As a supplier moves from country-country relationships with a customer, the dependence of each partner on the other will change. On one hand, the supplier becomes more dependent on the customer as all or most of its sales now go though one point of customer contact. This greater dependence is the biggest fear of suppliers considering the adoption of GAM. On the other hand, the customer typically cuts down the number of suppliers it uses, which in turn increases its dependence on the supplier. ${ }^{28}$ So the implementation of GAM creates a shift in bargaining power between supplier and customer. Which gets favoured depends on the situation and largely on which one is better coordinated on a global basis.

The mutual reduction in the number of bargaining and contracting points between supplier and customer (as shown earlier in the shift from Figure 1 to Figure 2) also greatly reduces transaction costs for both parties. ${ }^{29}$ We will discuss at various points how suppliers and customers can realise these reduced costs.

25 See exposition of this argument by Julian Birkinshaw, Omar Toulan, and David Arnold, (2001), "Global Account Management in Multinational Corporations: Theory and Evidence," Journal of International Business Studies, 32 (2), 231-248.

${ }^{26}$ For a review of information processing theory in relation to multinational companies, see William G. Egelhoff, "Information Processing Theory and the Multinational Enterprise," Journal of International Business Studies, Vol. 23, No. 3, pp. 341-368

27 This dependence can be seen in the light of resource dependency theory. See R.M. Emerson, "Power Dependence Relations," American Sociological Review, Vol. 27, pp. 31-40.

${ }^{28}$ This more dependent global customer can be seen as an increase in resources of the supplier, according to the resource-based view of strategy. See Birger Wernerfelt, "From Critical Resources to Corporate Strategy," Journal of General Management, 1989, Vol. 199114 (3): 4-12; and Jay B. Barney "Firm, Resources and Sustained Competitive Advantage," Journal of Management, Vol. 17 (1): 99-120

${ }^{29}$ For an exposition of transaction cost theory, see Oliver E. Williamson, Markets and Hierarchies: Analysis and Antitrust Implications, New York: The Free Press, 1975; and for relevance to international business, see Alain Verbeke, "The Evolutionary View of the MNE and the Future of Internalization Theory," Journal of International Business Studies, Vol. 34, No. 6, November 2003, pp. 498- 504 


\section{What Sort of GAM Programme?}

The most effective form of GAM programme differs from company to company, and even from customer to customer within the same company. Many aspects need to be taken into account before designing and implementing such a programme. Key questions include: how should it be organised, how should we implement it, and for which customers? Even if it is possible to isolate the top 30 or so customers, it would be an enormous task to have a separate customised GAM programme for each customer. How do you find the balance between customising GAM programmes and minimising the resources to implement them? A typical error is to start a GAM programme just because the customer asks for it and doing the absolute minimum required by the customer. The other end of the spectrum is implementing a full-on GAM programme without any potential added value in the current customer circumstances. It is important to find the right balance of GAM implementation for the company's situation.

Implementation of effective GAM programmes should achieve the right balance between local autonomy and global integration. Achieving both is difficult but necessary in global management..$^{\circ}$ The balance between the two depends particularly on the industry of the supplier. For example, a computer supplier probably needs higher levels of global integration than local autonomy, while a supplier of banking services probably needs the balance the other way around, and a capital goods supplier may be somewhere in between. This difference is illustrated in Figure 3. The best performing bank ( $\left.A_{1}\right)$ in terms of GAM is at one position on the "GAM Performance Frontier", while the best performing capital goods company $(\mathrm{B} 1)$ and the best performing compute company $\left(\mathrm{C}_{1}\right)$ are at different positions. Figure 3 also illustrates that other companies can be beneath the GAM performance frontier, that is, they under-perform in their GAM programmes in terms of both local autonomy and global integration. Such companies would be another bank (A2), another capital goods company (B2), and another computer company $\left(\mathrm{C}_{2}\right)$.

30 See the discussion of local responsiveness and global integration for MNCs in Prahalad and Doz and Bartlett and Ghoshal.
Local

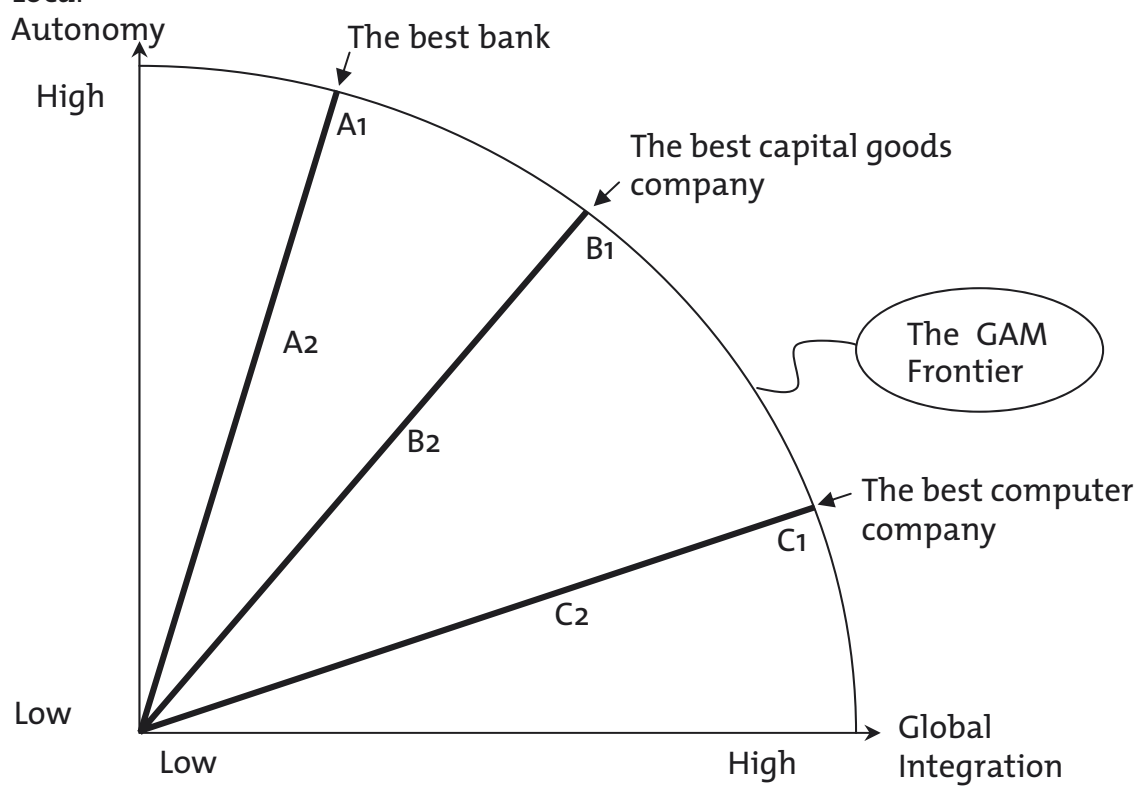

Figure 3-The Frontier of GAM Performance

From Global Account Management to Global Customer Management

When pursuing a global relationship with a customer, or potentially even a partnership, it is important to regard this customer as a whole company, not just as a purchasing department that happens to buy your products. Here, we can introduce the concept of Global Customer Management (GCM). It is not the same as GAM, nor is it something a company should do instead of GAM. GAM is the formal global account management programme, focused on coordinating the global business with the account. GCM is mainly a sales oriented programme where the most important focus is good coordination of the different sales contacts throughout the world. When, however, a supplier wants to leverage the global relationship with a customer into more than just a global sales contract, it is crucial to involve other areas of both companies in the global relationship. Furthermore, it is important that the GAM programme is not an operation that is separate from the rest of the company, but is integrated into the complete corporate organisation. This is where GCM comes in. GCM is the informal foundation fo a total integrated approach to GAM. This means that the GAM programme will be fused with the company's strategy and organisation. 


\section{Siemens' Global Customer Management Approach}

German electronics company Siemens' Corporate Accounts programme works with the idea that the partnership, not the product, provides the differentiation. The president of its Information \& Communications Corporate Accounts said: "Customers do not want a single point of contact, but rather a collaborative multifunctional team aligned to their organisation." For this collaborative, crossfunctional team, customer focus means having deep knowledge of the customer and its industry sector, focusing on the customer's business processes, having knowledge of and selling all of Siemens' assets. Next to the cross-functional team, sector boards provide a total portfolio to meet the customer needs. These boards provide the best in class in technology and innovation, integrated systems and services and a sector-focused business solution from all groups. With this structure it is the whole corporation, not just the global account manager that interacts with the global customer

With GCM, the entire corporation accommodates the GAM programme, which interacts with the rest of the organisation and is not a separate entity (see Figure 4). GAM will need to be a part of the total organisation aligned with all other company departments. Therefore, GCM will overlay the total company, and will incorporate the management processes needed to keep this integration effective. There should be a global representative for every global customer in the GAM programme, usually a global account manager (gam). The gam is responsible for the total global relationship with the account. He or she is organisationally situated within the GAM programme but in the integrated approach he or she will need to have a thorough network throughout the whole company. By having the gam work beyond the GAM organisation and into the rest of the company, it is possible to lift the programme beyond a transactional strategy to true global relationship management. One of the best methods to give the gam outreach to the rest of the company is the installation of a multi-disciplinary global account team (gat). This team will be a combination of people working in the GAM organisation and employees outside the global sales organisation. The gat needs to have members from different departments (such as R\&D, logistics and finance) to ensure a broader relationship network with the customer and within his or her own company. Therefore, the gat should not consist solely of sales personnel. In most cases the gam will be part of the gat, either as a member or as team leader. In the Dutch ingredients manufacturer DMV International, the composition of the gat is based on the customers' requirements. Next to the global key account manager, the core team will have members from particularly relevant departments for this customer, whereas the other departments are represented via a surround team that is less formalised. Fo example, if the customer is very active in new product introductions, the DMV R\&D and marketing departments will be well represented in the core team. If the customer particularly values projects for cost reduction then the focus will be on logistical and manufacturing representatives. As the core team members are encouraged to build relationships with their counterparts at the customer, this will give more connections and opportunities for cooperation with the customer.

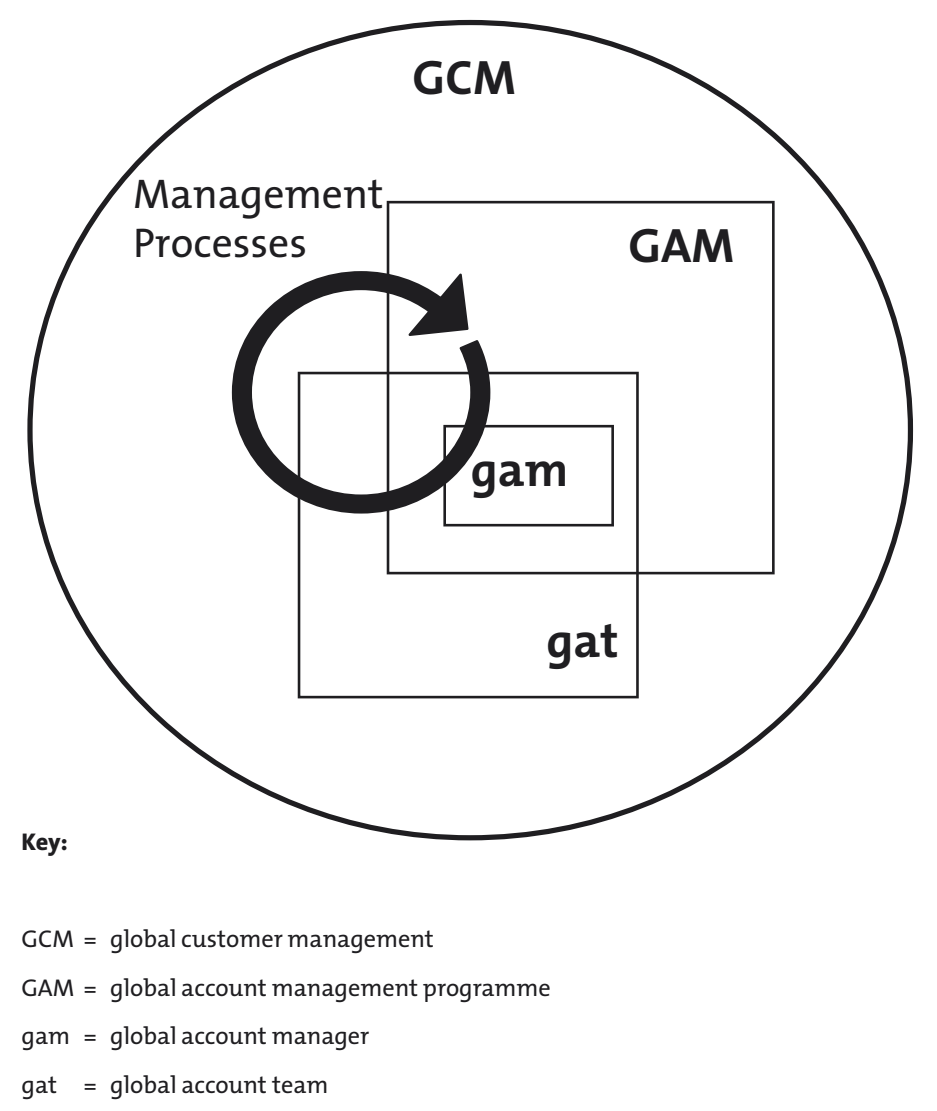

Figure 4-Components of Global Customer Management (GCM) 
Notes:

GCM covers the entire company. GAM is the formal part of GCM. The gam runs the GAM programme, and leads the gat, some of whose members are outside the forma GAM programme. Management processes, represented by the circling arrow, affect all components.

In summary, the focus for the implementation of a global relationship management programme should be on the integrated approach. When implementing a GAM programme it is important to embed it in the total organisation of the company. It is vital to perceive GAM as an integrated part of the organisation, and not as a separate programme. This way the GAM programme will get the respect and support within the organisation that it needs to function to its full potential. The basic idea is that it is important to look beyond the 'sales-purchasing' relationship and perceive the relationship with the customer as a combination of contacts within all departments and geographies.

\section{The Integrated Approach}

The two most important aspects of the integrated approach are the alignment and integration of the GAM programme with the rest of the organisation, and the management of the global relationship, which should go beyond sales to become an integrated approach towards all aspects of the customer's organisation. With this integrated approach, it will be easier to build a global relationship with the customer to deliver the added value enclosed in the opportunities of global business. Admittedly, taking the integrated approach for global customer management will be a more complex change than just adding a global coordination department to the organisation, but the rewards of truly global customer management will not be easy to reap without it. It is highly unlikely that a company with a very basic implementation of global account management will create a global partnership with its customers, as there are no methods to coordinate the relationship outside the sales department, and even if there are, it can be difficult to get company support behind certain global initiatives.

One of the important aspects of the integrated approach is the 'diamond' or 'web' structure in the relationships between the customer and the supplier. In a traditional 'sales-purchasing' situation, the structure of the relationship between the two companies resembles a 'bow-tie' with all the activity within one company leading to one person who has contact with the other company (account manager at the supplier, and purchasing officer at the customer). The integrated approach advocates a more integrated relationship structure that resembles a web or diamond shape in which employees from many different departments and functions have a direct relationship with each other and relevant people within the other company, as illustrated in Figure 5. This diamond structure enables the relationship to lift beyond being purely salesrelated towards a partnership. The Dutch food ingredients company DMV International has actively worked on implementing such a diamond structure, encouraging employees from departments such as marketing and R\&D to create active relationships with their counterparts, and other relevant people at the customer. This led to better understanding of the customers in the cross-functional account teams that were described earlier, and therefore account management that is customised to a greater degree. 

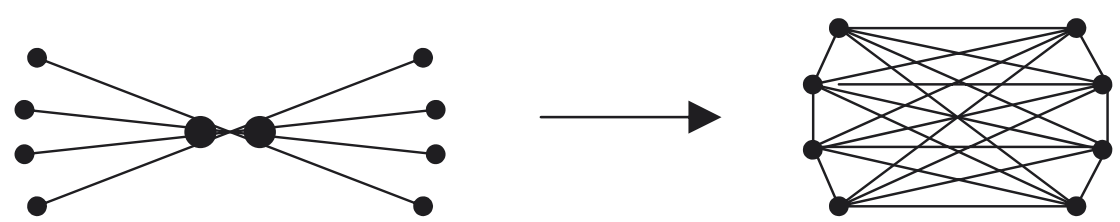

Figure 5 - From Bowtie to Diamond Relationships

Note

The right-side figure represents the multi-faceted, diamond-like aspect of a global customer-supplier relationship.

Our integrated approach results in a framework of four parts, which will also be used as the structure of this book: the foundation, the tools, the content, and the process. Figure 6 shows the complete framework and its components.

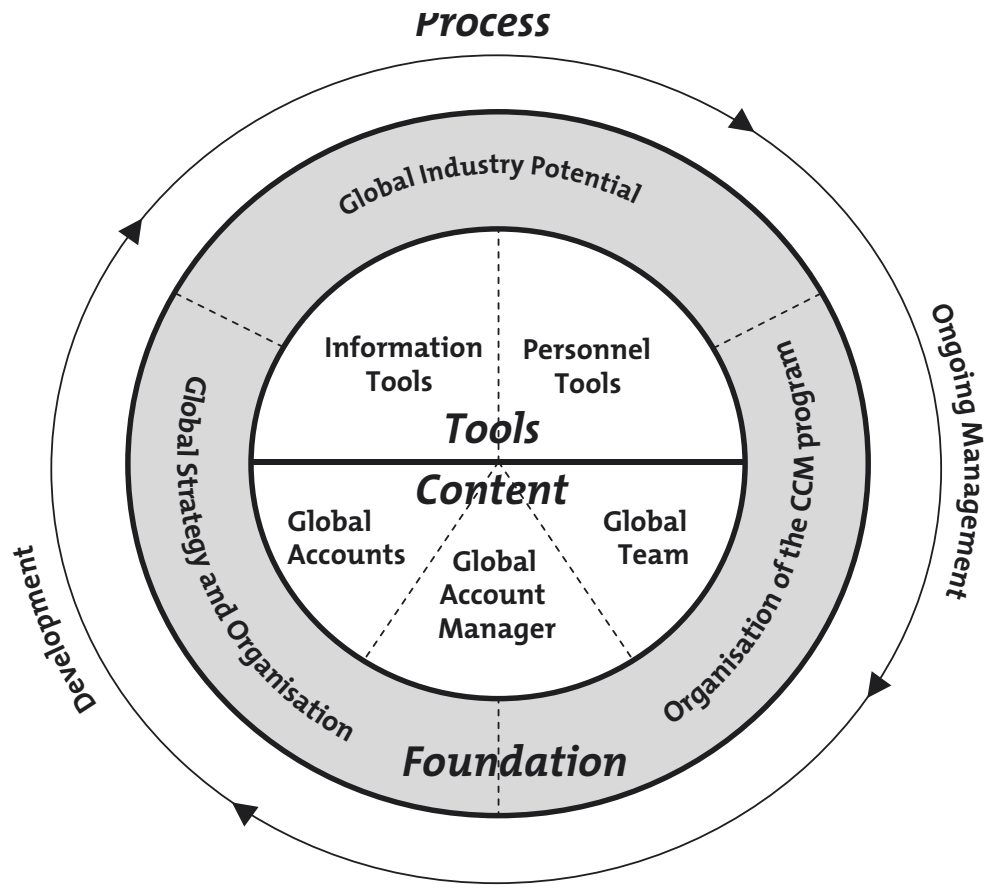

Figure 6 - Framework for Global Customer Management: the Integrated Approach
Foundation

The foundation of the integrated approach is the research and preparation that needs to be done before implementing the complete programme. This starts with determining the potential for starting a GCM programme, for which there can be many objectives. However, it is important that a company about to embark on launching GCM thoroughly determines the potential for its own situation. After the potential benefits and rewards have been determined, along with the necessary programme elements to tap into that potential, it is important to take care in exploring the company's strategy and organisation with respect to the impending GCM programme.

The type of products or services that a supplier offers its global customers will determine the need for global customer management. Typically, a supplier of commodities will have less need for complex coordination systems than a supplier of value added or complex products. This and other industry specifics will determine the elements needed within the GCM programme which should be analysed before the organisation is set up. Furthermore, the the alignment of the company's current strategy and organisation must be analysed with respect to a potential GCM programme. A company must have a global mindset for it to work smoothly within the total organisation. This means the global strategy of the company must be compatible with a potential GCM programme. The current structure of the organisation is also an important item for analysis, as the company needs to have the capabilities to act as a global supplier before showcasing this towards customers.

After the current situation has been thoroughly analysed, and if necessary, changed, the organisation of the GCM programme itself can be determined. There is not one best way, but it is important that sufficient care is taken to choose the best possible structure for the company's situation, as the organisation of the GCM is the bedrock on which sits the total GCM programme.

\section{KeyChoices}

After the company situation has been thoroughly examined and a suitable GCM organisation has been designed for the company's situation, it is important to take some care in providing the right content for the programme. The selection of the right global accounts is a crucial part of the content that will largely determine the success of 
the programme, and can be a daunting activity. Most customers will want to take part, but it is important to actually include only those customers that can be of added value to the programme otherwise GCM will end up as a costly operation of price (and probably profit) reduction.

The global account manager (gam) is another important part of the content of a GCM programme. As the GCM programme should lift GAM beyond a general sales approach, the gam should be more than a salesperson. It takes specific skills and seniority to be a gam that can juggle all the complexity of the global situation while stil being able to build on the extra potential. Therefore, selecting the right person for the position of gam can be the key to lifting the programme beyond global account coordination towards global customer management. Next to the global account manager, the global account team (gat) can have some influence in the affectivity with which the global customer is being managed. As the total relationship is a lot more complex than in a country-based relationship with a customer, the gam cannot handle the account completely on his or her own. Most companies have a formal or informal team that assists the gam in his or her activities. There are many different ways of setting up a global account team, but in the integrated approach it is important to include different capabilities in the team. This will help the programme to be more aligned with the rest of the organisation and will give it more recognition within the company. Chapter 7 discusses different forms of global account teams, like virtual networks, and cross-functional teams.

\section{Tools}

Once the GCM programme is designed and running, it will need to be supported by some tools to help it to run smoothly with the rest of the organisation, and to create the integrated approach. Customer information constitutes an important tool to reach this level of integration. Especially in a globally complex situation it can be hard to keep track of every piece of information involving the account. The position of the gam can sometimes resemble that of an account-specific "information manager." Many systems are available to help manage this information, but most companies agree it is hard to actually use this tool to its full potential and in an effective way to help the integrated approach. Chapter 8 discusses the use of information management systems, and the use of customer relationship management (CRM) systems and other knowledge management tools in GCM situations.
As employee perception can have a major effect on the programme, it is important to use tools that help motivate staff and give them reason to work hard for the success of the GCM programme. Incentives and compensation can be an important tool in its development. Many companies have to resort to some sort of 'double counting' to keep things fair for all involved parties.

Process

Once the GCM programme has been implemented, the company will want it to run as smoothly as possible. Companies have to realise GCM is a process, not a project, and manage it accordingly. The programme needs to be developed over time because improvements can be made and situations can change. Many processes are needed to run the programme to its full potential, to help develop it and make it fit in with the rest of the organisation and the current times. 


\section{Supporting Research}

Our work incorporates research on GCM by myself and various co-researchers from 1996 onwards, as well as learnings from interactions with executives in numerous executive programmes and conferences. In addition, this book builds on 20 years of research on the broader subjects of global strategy and organisation.

\section{Global Customer-Supplier Management Study}

The primary supporting research for this book is a study of global customer-supplie management that we conducted in 2003 and 2004, along with Professor Tomas Hult of Michigan State University. This involved first hand research at 31 MNCs, both global suppliers and global customers, listed in Table 1. This research involved personal interviews with over 60 senior executives, as well as a detailed multi-level survey completed by 27 executives. Information was obtained on the way global customersupplier relationship programmes can be implemented, the barriers that can be encountered, and best practices that can lead to extra advantage. In this study we coined the term, "Global Relationship Management (GRM)" to refer to either global customer management or global supplier management. ${ }^{3}$

${ }^{31}$ George S. Yip, G. Tomas M. Hult, and Audrey Bink, "Marketing Outcomes of Global Customer and Supplier Programs," Working Paper, London Business School, 2005
Table 1-Global Customer Supplier Relationships Researched

\begin{tabular}{|c|c|c|c|}
\hline Global Suppliers & Their Global & Global Customers & Their Global \\
\hline Researched & $\begin{array}{l}\text { Customers } \\
\text { researched }\end{array}$ & Researched & $\begin{array}{l}\text { Suppliers } \\
\text { researched }\end{array}$ \\
\hline Xerox (U.S.A.) & $\begin{array}{l}\text { ABB (Switzerland } \\
\text { Siemens (Germany) } \\
\text { Volkswagen (Germany) } \\
\text { HSBC (U.K.) }\end{array}$ & HSBC (UK) & $\begin{array}{l}\text { IBM (U.S.A.) } \\
\text { NCR (U.S.A. } \\
\text { British Airways (U.K.) } \\
\text { Lowe (U.S.) }\end{array}$ \\
\hline $\begin{array}{l}\text { DMV International) } \\
\text { (Netherlands }\end{array}$ & $\begin{array}{l}\text { Unilever (U.K./Neths.) } \\
\text { Novartis (Switzerland) } \\
\text { Numico (Neths.) }\end{array}$ & BG Group (U.K.) & $\begin{array}{l}\text { Schlumberger (France) } \\
\text { Bechtel (U.S.A.) }\end{array}$ \\
\hline Unilever (U.K./Neths.) & $\begin{array}{l}\text { Wal-Mart (U.S.A.) } \\
\text { Carrefour (France) } \\
\text { Tesco (U.K.) }\end{array}$ & Siemens (Germany) & 2 major U.S. suppliers \\
\hline WPP (U.K.) & $\begin{array}{l}\text { Vodafone (U.K.) } \\
\text { Kellogg } \\
\text { BP } \\
\text { Royal Dutch/Shell (Neths./U.K.) }\end{array}$ & WPP (U.K.) & Vodafone (U.K.) \\
\hline $\begin{array}{l}\text { Royal Dutch/Shell } \\
\text { (Neths/U.K.) }\end{array}$ & $\begin{array}{l}\text { Bosch (Germany) } \\
\text { Daimler-Chrysler (Germany) } \\
\text { Unilever (U.K./Neths.) } \\
\text { Wartsila (Finland) }\end{array}$ & & \\
\hline
\end{tabular}

In the primary set up of the study, eight global companies were selected as prime case studies. In half of these companies, the global customer management programme was studied, and in the other half, the global supplier management programme. For each company, the researchers identified two to four global customers (for the global customer management companies) or global suppliers (for the global supplier management companies). The study of each prime company was split into two levels and two sides, as shown in Figure 8. The researchers interviewed executives at the corporate/programme level and the account level in order to understand the general, companywide nature of the GRM programme, and the way in which the management of specific customers and suppliers might have been customised. At the corporate level, researchers interviewed the executive responsible for the whole global programme. At the account level, executives on both the managing side (e.g., a supplier) and the managed side (e.g., a customer) were interviewed in order to understand both sides of the relationship. This also allowed evaluation of the performance of the GRM 
programme from the viewpoint of both the managing and managed sides. Designing the research this way avoided the common problem of potential bias from having the same respondent report on both the programme and its performance.

\section{For each prime company in the study:}

\begin{tabular}{|c|c|c|}
\hline $\begin{array}{l}\text { Corporate } \\
\text { level }\end{array}$ & $\begin{array}{l}\text { Corporate Executive } \\
\text { for global business } \\
\text { or global } \\
\text { procurement } \\
\quad \text { - Interview } \\
\text { - Survey }\end{array}$ & \\
\hline $\begin{array}{l}\text { Account } \\
\text { level }\end{array}$ & $\begin{array}{l}\text { Global account } \\
\text { manager or global } \\
\text { supplier manager } \\
\quad \text { - Interview } \\
\quad \text { - Survey }\end{array}$ & $\begin{array}{l}\text { Counterpart of } \\
\text { global account } \\
\rightarrow \text { manager or global } \\
\text { supplier manager } \\
\quad \text { - Interview } \\
\quad \text { - Survey }\end{array}$ \\
\hline
\end{tabular}

Figure 7- Levels in the Global Customer-Supplier Management Study

Large Sample Survey

I and a co-author (Professor David B. Montgomery of Stanford Business School) developed a questionnaire about global account management, had it completed by 19 senior international executives from 165 multinational companies and conducted various statistical tests. ${ }^{32}$

32 This study is reported in Montgomery, David B. and Yip, George S., "The Challenge of Global Custome Management," Marketing Management, Vol. 9, No. 4, Winter 200o, pp. 22-29; and in Montgomery, David B., George S. Yip, and Belen Villalonga, "Demand For and Use of Global Account Management, Cambridge, MA: Marketing Science Institute, Report No. 99-115, 1999
Our sample came from four different sources: one mail survey and three convenience samples from senior-level executive education programmes conducted at Stanford and UCLA business schools, all during 1997. In all four samples, respondents were nearly al at the level of vice president or higher.

Statistical tests showed the four samples provided very similar results and could be pooled into one sample for analysis. The respondent multinational companies came from a very wide mix of industries and from 33 different countries spread across al regions of the world: North, South and Central America; Western and Eastern Europe; East Asia; Africa; and Oceania. On average, the companies had operations in four of these regions. U.S. companies made up 70 per cent (133 out of 191) of the sample. Median company revenues were $\$ 1,956$ million (just below the U.S. Fortune 500 cutoff of 1997).

\section{GAM Forum}

Additional supporting research comes from six sessions of a global account management forum based in London that we conducted during 2001. During these sessions, senior executives from 13 multinational companies discussed issues about GAM. These companies included: BP Amoco, Castrol International, Herbert Smith (a leading law firm), IBM, Hill \& Knowlton, Merrill Lynch, PricewaterhouseCoopers, Regus (a leading provider of office space around the world), Siebel Systems (a leading provide of CRM and other systems), Spirent (a leading telecommunications technology company), Standard Chartered Bank, Wunderman (a marketing services company in the WPP group), and Xerox.

Casestudies

We wrote detailed case studies about Hewlett-Packard's global account management programme and how the Young \& Rubicam advertising agency managed the Star Alliance (of airlines) as a global customer. ${ }^{33}$

33 See Angela Andal-Ancion, under the direction of George S. Yip, 'Star Alliance (B): A Global Customer,' European Case Clearing House, No. 504-128-1; and also G. S. Yip and Madsen, T.L., 'Hewlett-Packard (A): The Global Sales Problem' and 'Hewlett-Packard (B): The Global Account Solution,' in Global Marketing, Johansson, J.K., Irwin, 1997, pp. 684-691; Hewlett-Packard (A) in de la Torre, Jose, Doz, Yves, and Devinney, Tim, Managing the Global Corporation: Cases in Strategy and Management, McGraw-Hill 2001, pp. 364-374. 
We conducted supplemental interviews with senior executives involved in global customer management at BT, Citigroup, Dun \& Bradstreet, Ford Motor Company, and Reuters. I advised a research study conducted by McKinsey \& Company on how multinational suppliers to retailers perceived the effects of the internationalisation of retailers on their business.

\section{Executive Education Programmes and Conferences}

I benefited from interacting with participants in executive education programmes I conducted about global customer management for ABN Amro, Deutsche Bank, and Wallenius Wilhelmsen Lines. I also spoke at the St. Gallen GAMPRO programme in 2004 2005, and 2006, at which participants included global account directors and managers from Areva T\&D, Balzers, Brewer Science, Brita, Ciba Specialty Chemicals, Clariant International, Degussa, Deutsche Bank, Dow Chemical, Experian-Scorex, Frantschach Industrial Packaging, GN Netcom, Halcrow, Hubert+Suhner, IBM, MAN Turbo, Mond Packaging, Narimpex, Nike, Oracle, Prionics, Rockwell, SAP, Scandinavian Airlines System, Siemens, SIG Combibloc, Sika, Sun Chemical, SWIFT, Swisscom Fixnet, Swiss International Airlines, Telekurs Financial Information, Vodafone, W.L. Gore, and Wacker Chemie.

In 2004, both authors participated in a special workshop in London on global customer management organised by ITC Solutions. Participants included executives from WPP, C\&A, Unisys, Intel, IBM, BT, Delta, Royal Dutch Shell and Hewlett-Packard. Lastly, in late 2006, I presented and discussed the framework of this book at the St Gallen University annual conference on global account management. Participants included executives from AMC Account Management Center, Bossard, Citigroup, Farnel InOne, Heidelberger, Holcim Group, Kone, Lufthansa Cargo, Marriott International, Philips International, PricewaterhouseCooper, Rogers Corporation, Schott, Shell Chemical, Sika Services, Suez Industrial Solutions, Tesco Stores, Vectia, Vitra International, Voith Paper Fabrics, and Zurich Insurance.

\section{Erasmus Research Institute of Management - ERIM}

Inaugural Addresses Research in Management Series

ERIM Electronic Series Portal: http://hdl.handle.net/1765/1

Balk, B.M., The residual: On monitoring and Benchmarking Firms, Industries and Economies with respect to Productivity, 9 November 2001, ElA-07-MKT,

ISBN 90-5892-018-6, http://hdl.handle.net/1765/300

Benink, H.A., Financial Regulation; Emerging from the Shadows, 15 June 2001 EIA-02-ORG, ISBN 90-5892-007-0, http://hdl.handle.net/1765/339

Bleichrodt, H., The Value of Health, 19 September 2008, EIA-2008-36-MKT, ISBN/EAN 978-90-5892-196-3, http://hdl.handle.net/1765/13282

Boons, A.N.A.M., Nieuwe Ronde, Nieuwe Kansen: Ontwikkeling in Management Accounting \& Control, 29 September 2006, ElA-2006-029-F\&A, ISBN 90-5892-126-3, http://hdl.handle.net/1765/8057

Brounen, D., The Boom and Gloom of Real Estate Markets, 12 December 2008, EIA-2008-035-F\&A, ISBN/EAN 978-90-5892-194-9,

http://hdl.handle.net/1765/14001

Bruggen, G.H. van, Marketing Informatie en besluitvorming: een interorganisationeel perspectief, 12 October 2001, EIA-06-MKT, ISBN 90-5892-016-X http://hdl.handle.net/1765/341

Commandeur, H.R., De betekenis van marktstructuren voor de scope van de onderneming. 05 June 2003, EIA-022-MKT, ISBN 90-5892-046-1, http://hdl.handle.net/1765/427

Dale, B.G., Quality Management Research: Standing the Test of Time; Richardson, R., Performance Related Pay-Another Management Fad?; Wright, D.M., From Downsize to Enterprise: Management Buyouts and Restructuring Industry. Triple inaugural address for the Rotating Chair for Research in Organisation and Management. March 28 2001, EIA-01-ORG, ISBN 90-5892-006-2,

http://hdl.handle.net/1765/338 
Dekimpe, M.G., Veranderende datasets binnen de marketing: puur zegen of bron van frustratie?, 7 March 2003, EIA-17-MKT, ISBN 90-5892-038-0,

http://hdl.handle.net/1765/342

Dijk, D.J.C. van, “Goed nieuws is geen nieuws", 15 November 2007,

EIA-2007-031-F\&A, ISBN 90-5892-157-4,

http://hdl.handle.net/1765/10857

Dissel, H.G. van, “Nut en nog eens nut" Over retoriek, mythes en rituelen in informatiesysteemonderzoek, 15 February 2002, EIA-08-LIS, ISBN 90-5892-018-6, http://hdl.handle.net/1765/301

Dul, J., "De mens is de maat van alle dingen" Over mensgericht ontwerpen van producten en processen., 23 May 2003, EIA-19-LIS, ISBN 90-5892-038-X, http://hdl.handle.net/1765/348

Ende, J. van den, Organising Innovation, 18 septemb er 2008, EIA-2008-034-ORG, ISBN 978-90-5892-189-5, http://hdl.handle.net/1765/13898

Groenen, P.J.F., Dynamische Meerdimensionele Schaling: Statistiek Op De Kaart, 31 March 2003, EIA-15-MKT, ISBN 90-5892-035-6, http://hdl.handle.net/1765/304

Hartog, D.N. den, Leadership as a source of inspiration, 5 October 2001, EIA-05-ORG, ISBN 90-5892-015-1, http://hdl.handle.net/1765/285

Heck, E.van, Waarde en Winnaar; over het ontwerpen van electronische veilingen, 28 June 2002, EIA-10-LIS, ISBN 90-5892-027-5, http://hdl.handle.net/1765/346

Heugens, Pursey P.M.A.R., Organization Theory: Bright Prospects for a Permanently Failing Field, 12 September 2008, EIA-2007-032 ORG, ISBN/EAN 978-90-5892-1758, http://hdl.handle.net/1765/13129

Jong, A. de, De Ratio van Corporate Governance, 6 October 2006, ElA-2006-028-F\&A, ISBN 90-5892-128-X, http://hdl.handle.net/1765/8046
Kaptein, M., De Open Onderneming, Een bedrijfsethisch vraagstuk, and Wempe, J., Een maatschappelijk vraagstuk, Double inaugural address, 31 March 2003, EIA-16-ORG, ISBN 90-5892-037-2, http://hdl.handle.net/1765/305

Knippenberg, D.L. van, Understanding Diversity, 12 October 2007,

EIA-2007-030-ORG, ISBN 90-5892-149-9, http://hdl.handle.net/1765/10595

Kroon, L.G., Opsporen van sneller en beter. Modelling through, 21 September 2001, EIA-03-LIS, ISBN 90-5892-010-o, http://hdl.handle.net/1765/340

Magala, S.J., East, West, Best: Cross cultural encounters and measures, 28 September 2001, EIA-04-ORG, ISBN 90-5892-013-5, http://hdl.handle.net/1765/284

Meijs, L.C.P.M., The resilient society: On volunteering, civil society and corporate community involvement in transition, 17 September 2004, EIA-2004-024-ORG, ISBN 90-5892-000-3, http://hdl.handle.net/1765/1908

Oosterhout, J., Het disciplineringsmodel voorbij; over autoriteit en legitimiteit in Corporate Governance, 12 September 2008, EIA-2007-033-ORG, ISBN/EAN 978-90-5892-183-3, http://hdl.handle.net/1765/13229

Osselaer, S.M.J.van, Of Rats and Brands: A Learning-and-Memory Perspective on Consumer Decisions, 29 October 2004, ElA-2003-023-MKT, ISBN 90-5892-074-7, http://hdl.handle.net/1765/1794

Pau, L-F., The Business Challenges in Communicating, Mobile or Otherwise, 31 March 2003, EIA-14-LIS, ISBN 90-5892-034-8, http://hdl.handle.net/1765/303

Peccei, R., Human Resource Management And The Search For The Happy Workplace. January 15, 2004, EIA-021-ORG, ISBN 90-5892-059-3,

http://hdl.handle.net/1765/1108

Pelsser, A.A.J., Risico en rendement in balans voor verzekeraars. May 2 2003, EIA-18-F\&A, ISBN 90-5892-041-o, http://hdl.handle.net/1765/872 
Rotmans, J., Societal Innovation: between dream and reality lies complexity. June 3 2005, EIA-2005-026-ORG, ISBN 90-5892-105-o, http://hdl.handle.net/1765/7293

Smidts, A., Kijken in het brein, Over de mogelijkheden van neuromarketing, 25

October 2002, EIA-12-MKT, ISBN 90-5892-036-4, http://hdl.handle.net/1765/308

Smit, H.T.J., The Economics of Private Equity, 31 March 2003, EIA-13-LIS, ISBN 90-5892-033-X, http://hdl.handle.net/1765/302

Stremersch, S., Op zoek naar een publiek..., April 15 2005, EIA-2005-025-MKT, ISBN 90-5892-084-4, http://hdl.handle.net/1765/1945

Verbeek, M.,Onweerlegbaar bewijs? Over het belang en de waarde van empirisch onderzoek voor financierings- en beleggingsvraagstukken, 21 June 2002,

EIA-09-F\&A, ISBN 90-5892-026-7, http://hdl.handle.net/1765/343

Waarts, E., Competition: an inspirational marketing tool, 12 March 2004

EIA-2003-022-MKT, ISBN 90-5892-068-2, http://ep.eur.nl/handle/1765/1519

Wagelmans, A.P.M., Moeilijk Doen Als Het Ook Makkelijk Kan, Over het nut van grondige wiskundige analyse van beslissingsproblemen, 20 September 2002 ,

EIA-11-LIS, ISBN 90-5892-032-1, http://hdl.handle.net/1765/309

Wynstra, J.Y.F., Inkoop, Leveranciers en Innovatie: van VOC tot Space Shuttle, February 17 2006, EIA-2006-027-LIS, ISBN 90-5892-109-3, http://hdl.handle.net/1765/7439 